Chirurgia (2018) 113: 651-667

No. 5, September - October

Copyright $@$ Celsius

http://dx.doi.org/10.21614/chirurgia.113.5.651

\title{
Soft Tissue Infections in Diabetic Patients
}

\author{
Petronel Mustățea ${ }^{1,2}$, Cătălin Bugă', Horia Doran, ${ }^{1,2}$, Octavian Mihalache ${ }^{1,2}$, Florin Teodor Bobîrcă', ${ }^{1,2}$, \\ Dragoș Eugen Georgescu ${ }^{1,2}$, Alexandra Agache ${ }^{1,2}$, Cristina Jauca', Andra Bîrligea ${ }^{1}$, Ovidiu Chiriac', $^{1}$, \\ Vlad Marin', Traian Pătrașcu' ${ }^{1,2}$
}

1"Dr. I. Cantacuzino" Clinical Hospital, Department of General Surgery “I. Juvara”, Bucharest, Romania

2"Carol Davila" University of Medicine and Pharmacy, Bucharest, Romania

Corresponding author: Associate Professor Horia Doran

"Carol Davila" University of Medicine and Pharmacy

"Dr. I. Cantacuzino" Clinical Hospital

$1^{\text {st }}$ Surgical Department

Bucharest, Romania

E-mail: doranh2003@yahoo.com

\section{Rezumat}

\section{Supuratiile de părți moi la pacientul diabetic}

Introducere: pacientul cu diabet zaharat prezintă o susceptibilitate crescută la infecții, cu potențial evolutiv negativ conducând la o morbiditate şi mortalitate crescute față de populația generală. Cauza este reprezentată de alterarea mecanismelor imune de apărare, mediul hiperglicemic conducând la alterarea funcției neutrofilelor, supresia sistemului antioxidant şi a activității umorale, micro şi macroangiopatia sistemică, neuropatia, deprimarea activității antibacteriene a tractului genitourinar şi digestiv. Infectiile localizate la nivelul părților moi (tegument, fascii şi aponevroze, țesut subcutanat, muşchi) la pacientul diabetic necesită o abordare medico - chirurgicală complexă în care tratamentul chirurgical agresiv trebuie să fie completat de echilibrare metabolică şi antibioterapie susținută.

Material şi Metodă: aceste particularități vor fi expuse şi analizate într-un studiu descriptiv retrospectiv realizat în Clinica de Chirurgie Generală "I. Juvara" a Spitalului Clinic Dr I. Cantacuzino în perioada 2013-2017, care a urmărit tipul leziunilor, localizarea acestora, germenii implicați, comorbiditățile, parametrii bioumorali, tratamentul antibiotic şi chirurgical precum şi evoluția postoperatorie. Studiul nu include pacienții cu infecții localizate la nivelul piciorului diabetic.

Rezultate: Au fost identificați 150 de pacienți diabetici cu infecții de părți moi localizate la nivelul membrului superior, gambei, coapsei, perineului, peretelui abdominal şi toracic. Cea mai frecventă localizare s-a regăsit la nivelul membrului inferior (54\%). Prezența acestor infecții a fost mai mare la bărbați (55\%), iar decada de 
vârstă cea mai afectată a fost 60-69 ani (38\%). Majoritatea pacienților au avut diabet zaharat tip II (93\%). Dintre comorbiditățile asociate regăsim bolile cardio-vasculare şi obezitatea ca fiind cele mai frecvente explicând într-o mare masură evoluția dificilă, potențial letală a acestei patologii. Din punct de vedere bacteriologic se identifică o floră plurimicrobiană, stafilococul auriu fiind cel mai frecvent întâlnit. Tratamentul antibiotic a fost inițiat imediat empiric, ulterior conform antibiogramei, cele mai utilizate clase de antibiotic administrate fiind cefalosporinele şi carbapenemii. Intervențiile chirurgicale au fost în marea majoritate de debridare excizională şi necrectomie, în puține cazuri fiind necesară amputatia de membru. Particular, numărul de intervenții chirurgicale efectuate la acelaşi pacient şi în aceeaşi internare a fost între 1 şi 7 intervenții.

Concluzii: Infecțiile de părți moi la pacientul diabetic prezintă un aspect heterogen, cu particularități specifice care impun o examinare clinică atentă, tratament multidisciplinar ce include intervenții chirurgicale rapide, seriate menite să stăpânească agresiunea tot mai crescândă a germenilor implicați. Deciziile terapeutice rapide şi adaptate fiecarui caz, urmărirea atentă a plăgilor precum şi a stării generale a pacientului de mai multe ori pe zi, sunt esențiale pentru obținerea unor rezultate post-operatorii favorabile.

Cuvinte cheie: infecții de părți moi, fasciita necrotizantă, diabet zaharat, debridare excizionala.

\section{Abstract}

Background: the patient with diabetes has an increased susceptibility to infections, with negative evolutionary potential leading to increased morbidity and mortality compared to the general population. The cause is the alteration of immune defense mechanisms, the hyperglycemic environment leading to alteration of neutrophil function, suppression of the antioxidant system and humoral activity, systemic micro and macroangiopathy, neuropathy, depression of antibacterial activity of the genitourinary and digestive tract. Infections localized at the soft tissue (skin, fascia and aponeurosis, subcutaneous tissue, muscles) in the diabetic patient require a complex medico-surgical approach in which aggressive surgical treatment should be complemented by metabolic balancing and sustained antibiotic therapy.

Materials and methods: these peculiarities will be exposed and analyzed in a retrospective descriptive study performed at the General Surgery Clinic 'I. Juvara' of the clinical hospital 'Dr. I. Cantacuzino', during the period of Jan. 2013- Dec.2017, which followed the type of lesions, their localization, the germs involved, the comorbidities, the biologic parameters, the antibiotic and surgical treatment as well as the postoperative evolution. The study does not include patients with localized infections in the diabetic foot, a particular pathological entity that will be analyzed separately in a separate study.

Results: 150 diabetic patients with soft tissue infections localized in the upper limb, calf, thigh, perineum, abdominal and thoracic wall were identified. The most frequent localization was found in the lower limb (54\%). The incidence of these infections was higher in males (55\%), and the most affected age group was 60-69 years (38\%). Most patients had type II diabetes (93\%). Among the associated comorbidities, cardiovascular diseases and obesity are the most common, explaining to a large extent the complicated evolution, potentially lethal of this pathology. From the bacteriological perspective, a plurimicrobian flora is identified, staphylococcus aureus being most frequently encountered. The antibiotic treatment was initiated immediately empirically, subsequently according to the antibiogram; the most commonly used antibiotic classes being cephalosporins and carbapenems. Surgical interventions were in their majority of debridement and necrectomy, but in a few cases limb amputation was necessary. In particular, the number of surgical interventions performed in the same patient and in the same hospital stay was between 1 and 7 interventions. Conclusions: Soft tissue infections in the diabetic patient have a heterogeneous aspect with specific 
particularities requiring careful clinical examination, multidisciplinary treatment including rapid, serial surgical interventions to control the growing aggression of the germs involved. Fast and caseadapted therapeutic decisions, careful observation of the patient's general condition and of the wound several times a day are essential to achieving favorable postoperative outcomes.

Key words: soft tissue infections, necrotizing fasciitis, diabetes mellitus, excisional debridement

\section{Background}

Hyperglycemia, sensory neuropathy and vascular damage (micro and macroangiopathy) are pathological changes present in all patients with diabetes mellitus that predispose to skin and soft tissue infections with the most frequent localization being at the foot (a particular pathological entity - "the diabetic foot"). However, this localization is not the only one, minimal skin lesions in any anatomic region can evolve to severe infections, generating cellulites, lymphangitis, abscesses or even necrotizing fasciitis when microbial aggression is increased.

The diabetic patient has a 5-fold higher risk than the general population of developing an infectious pathology evolving towards complications, leading to increased hospitalization time, morbidity and mortality. The cause is the alteration of immune defense mechanisms, the hyperglycemic environment leading to alteration of neutrophil function, suppression of the antioxidant system and humoral activity, systemic micro and macroangiopathy, neuropathy, depression of antibacterial activity of the genitourinary and digestive tract.

Regarding the bacterial flora, the group A and group B streptococcus, staphylococcus and anaerobic bacteria were isolated most frequently in the diabetic patient. Antibiotic therapy should be initiated immediately, empirically with broad spectrum antibiotics and subsequently adapted to the antibiogram.

Surgical treatment requires an emergency approach, in many cases multiple reinterventions for debridement and excision of necrotic tissues being needed.

In this context, the article aims to evaluate the clinical and treatment particularities of soft tissue infections in the diabetic patient based on the experience gained in the General Surgery Clinic "I. Juvara" of the Clinical Hospital 'Dr. I Cantacuzino.

\section{Materials and Methods}

A retrospective descriptive study including 150 diabetic patients hospitalized and operated in the clinic for skin and soft tissue infections was carried out between January 2013 and December 2017. Diabetic patients with soft tissue infections localized in the foot ('diabetic foot' treated as a separate entity) and patients with non-surgical injuries (lymphangitis and cellulite lesions responding favorably only to conservative treatment - antibiotic therapy) were excluded from the study.

Ethical local committee approved this study.

The main pathological entities identified and surgically treated were abscesses, parcelar skin necrosis and necrotizing fasciitis located in the lower and upper limb, perineum, abdominal and thoracic wall.

The clinical particularities of the lesions at the time of admission and their evolution, the antibiotic treatment and the vital function support and metabolic rebalancing were evaluated. Special emphasis has been placed on the analysis of the particularities of surgical treatment, this being the decisive therapeutic element that can provide a favorable evolution in cases of advanced and aggressive disease such as necrotizing fasciitis.

\section{Results}

Of the 150 patients analyzed, 58\% (88) were 
men and $42 \%$ (62) were women. The decade of age most affected by this pathology is $60-69$ years, at a rate of 38\% (Figs. 1 and 2).

Most patients had type II diabetes, with only $7 \%$ of patients diagnosed with type I diabetes. Of the patients with type II diabetes, $86 \%$ were in treatment with oral antidiabetics with elevated glycemic values at the time of admission. This is explained by a low compliance to treatment, the patient administering his medication on his own criteria and not according to the indications provided based on glycemic values. Also, an improper diet, regarding the carbohydrate intake recommended by the specialist for 24 hours has been noted at $91 \%$ of the patients (Fig. 3).

It is known that in the diabetic patient with localized infection at any level, glycemic values are higher than normal, even with the correct antidiabetic treatment administered until that time (Fig. 4). Thus, in patients operated with high glycemic values that cannot be corrected, there is suspicion of the presence of an unidentified suppurative lesion or the progression of the infectious process requiring a careful examination of the wounds at the patient's bed or under anesthesia in the operating room. During hospitalization, all patients had fasting

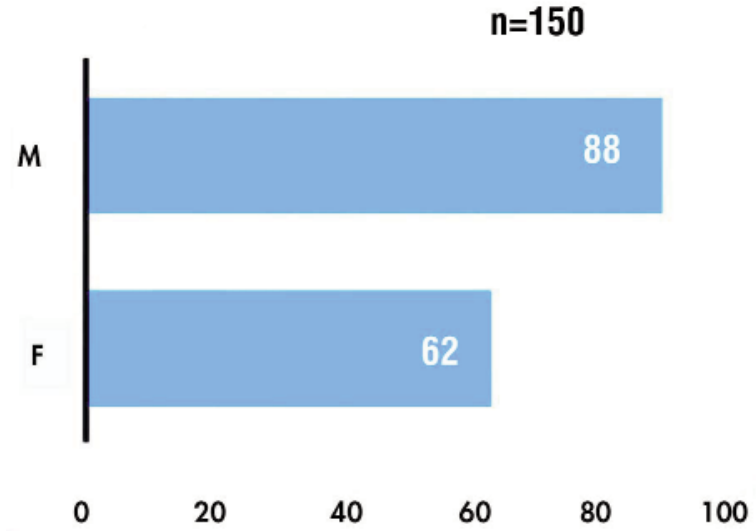

Figure 1. Sex distribution

insulin to correct glycemic values. Its advantages over oral antidiabetics are multiple: it provides a more effective correction of serum glucose, it can be administered to patients who cannot be feed by subcutaneous or intravenous administration by $10 \%$ glucose infusion corrected proportionally. Subsequently, at the time when the infectious process is mastered, the postoperative wound is healing and the patient is ready for discharge, it is attempted to switch to oral antidiabetic treatment. If glycemic values cannot be restored to normal

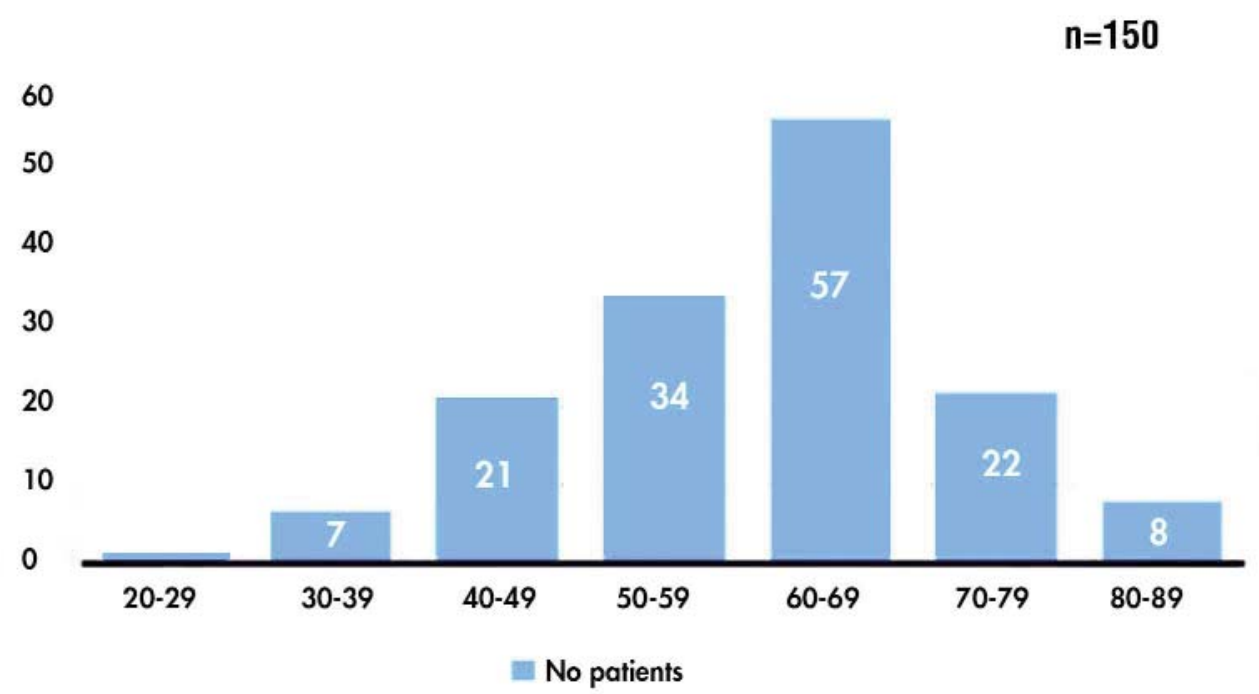

Figure 2. Age distribution 
$n=150$

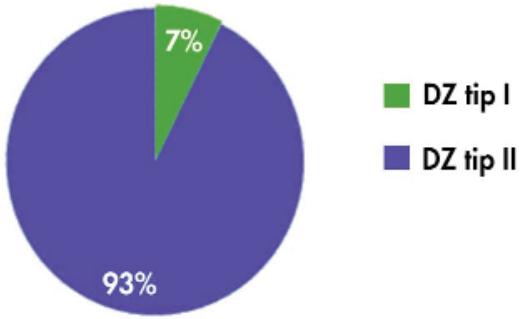

Figure 3. Distribution of patients regarding the type of diabetes

levels, thepatient will remain insulin-treated (becoming a diabetic type II insulin-necessitating patient).

Localization of infections was in over half the cases $(54 \%)$ in the lower limb - thigh and calf and in descending order: perineum, abdominal wall, thoracic, inguinal and buttock region. The lowest frequencies were in the upper limb (3\%) (Fig. 5).

Diabetic patients with soft-tissue infections have presented a multiple-associated pathology. In frequency order, we identified cardiovascular diseases (high blood pressure-HBP, ischemic heart disease-CID, congestive heart failure$\mathrm{CHF}$, atrial fibrillation-AFI, peripheral arterial disease-PAD, strokes in medical history). Obesity was identified in $17 \%$ of cases. Chronic renal failure along with neoplasia and chronic viral hepatitis have completed the associated pathology picture (Fig. 6).

Diagnose at admission varied according to the type of lesion and the anatomical region involved. Calf fasciitis was the most common diagnosis present at admission. We also noted a significant number of fasciitis (48\%), of which 23 (15\%) were necrotizing fasciitis located in the abdominal and thoracic wall, perineum, thigh and scrotum (Fournier Gangrene) (Fig. 7).

Regarding the symptomatology at admission, it was dominated by pain syndrome and local and generalized septic phenomena. Pain syndrome was characterized by intense, progressive local pain, which did not respond to the usual painkiller treatment. Local septic phenomena were represented by central fluctuation inflammation suggesting the presence of a fluid

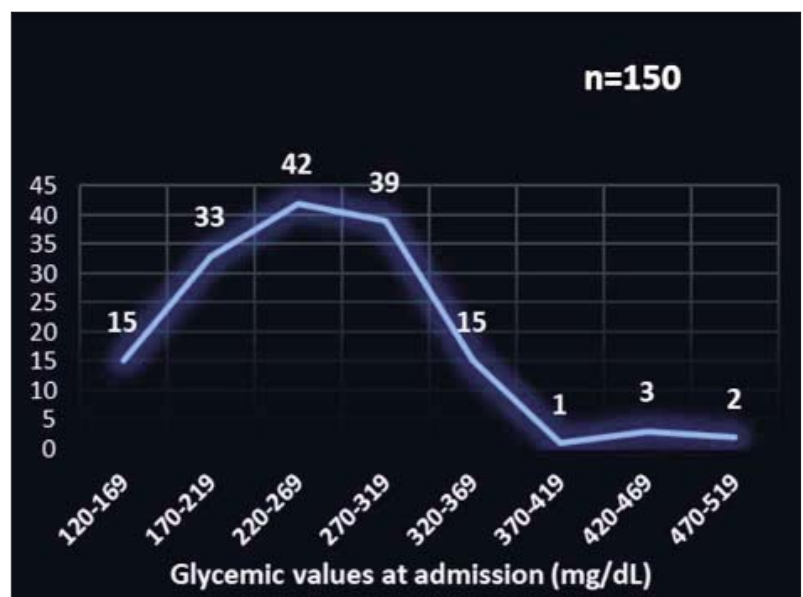

Figure 4. The distribution of glycemic values at presentation

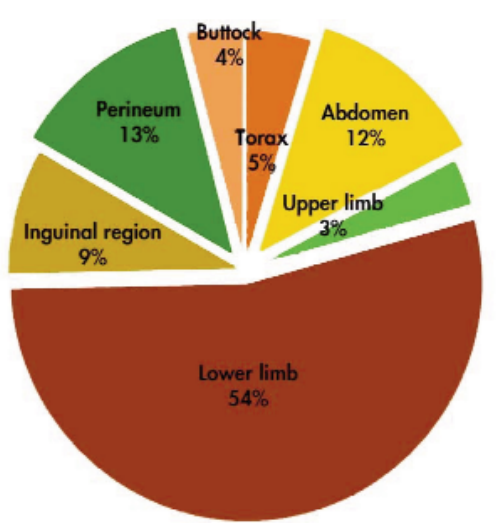

$n=150$

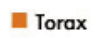

Abdomen

- Upper limb

- Lower limb

Inguinal region

- Perineum

Euttock

Figure 5. Distribution of patients regarding the localization of the tumor

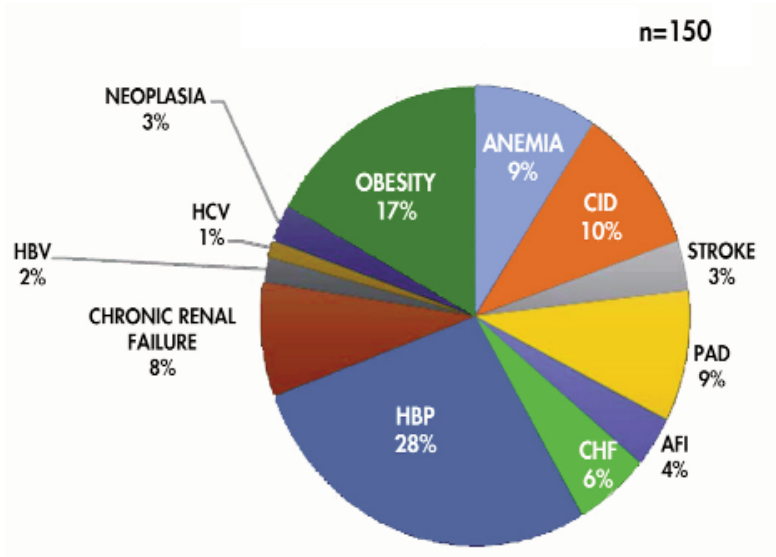

Figure 6. The distribution of the associated pathology

collection (Fig. 8), skin fistulae with persistent purulent secretions, soft tissue necrosis, skin 


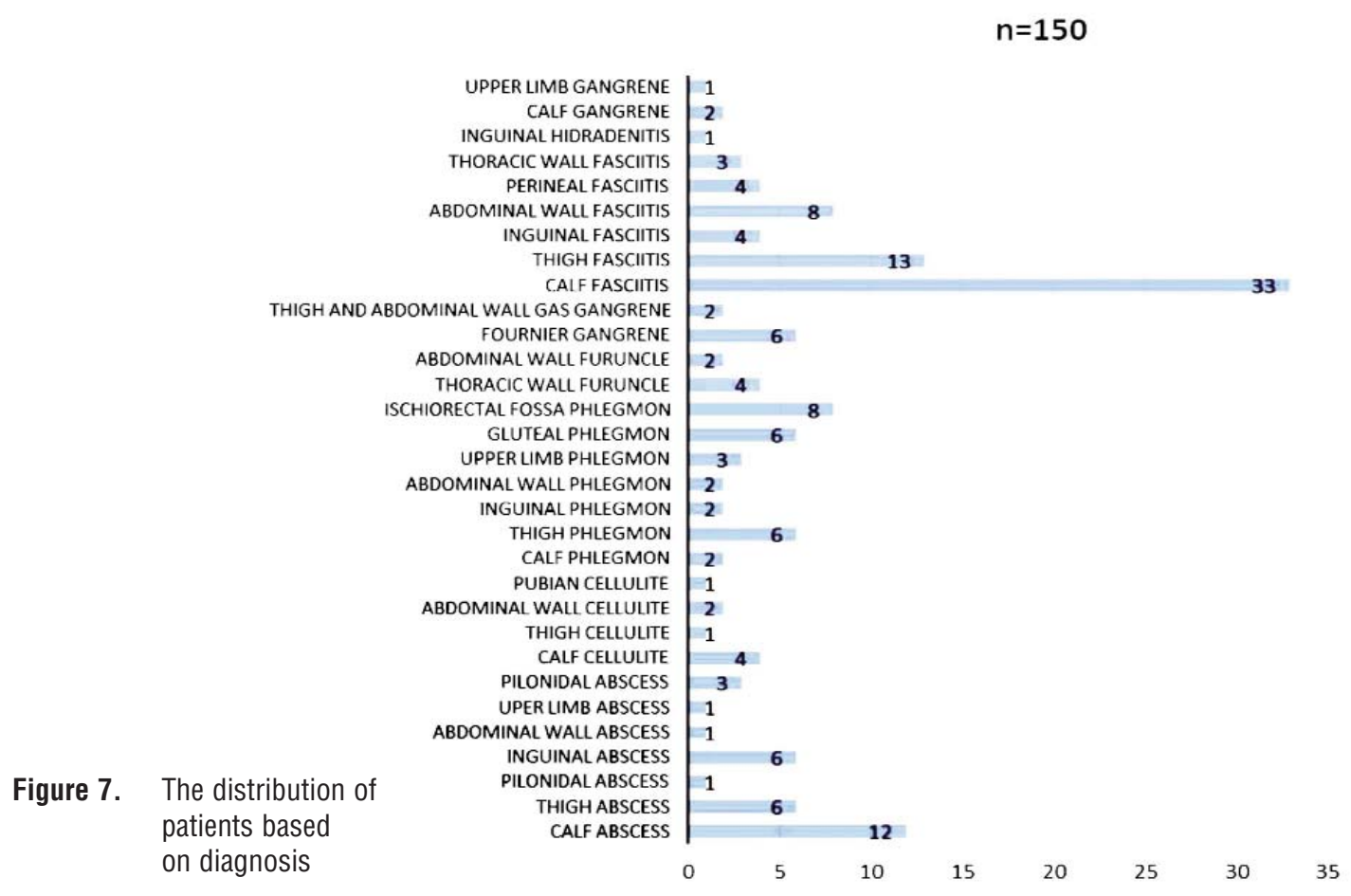

necrosis, subcutaneous tissue and fascia necrosis (Figs. 9, 10). The lesions can often be extended due to their rapidly evolving nature, but also to the self-administered empirical treatment that delays the presentation to the specialist doctor.

Perianal location of an abscess generates major pain symptoms accompanied by fever and chills, mictional and transit disorders due to local sepsis. These abscesses can spontaneously fistulate, at which point the pain diminishes till regresion with a purulent discharge. In the case of the ischiorectal fossa phlegmon or pelvisubperitoneal abscess, the clinical examination should be carefully done because often local inflammatory phenomena may be discrete, with generalized septic condition being the primary manifestation (Fig. 11).

Of the soft tissue infections, the most aggres-

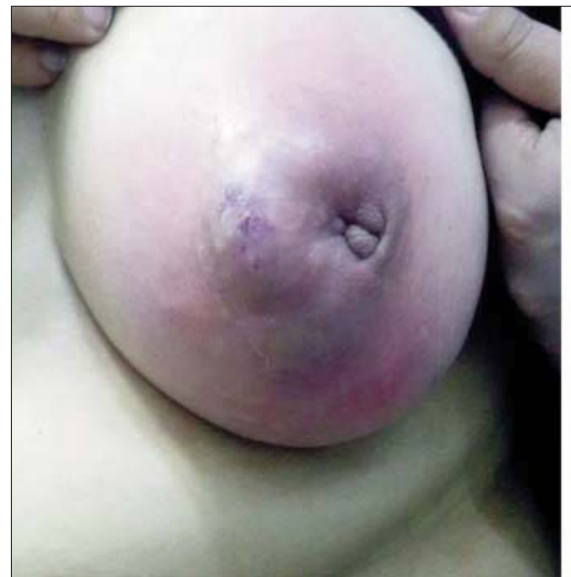

Figure 8. Breast abscess with emerging spontaneous fistulae

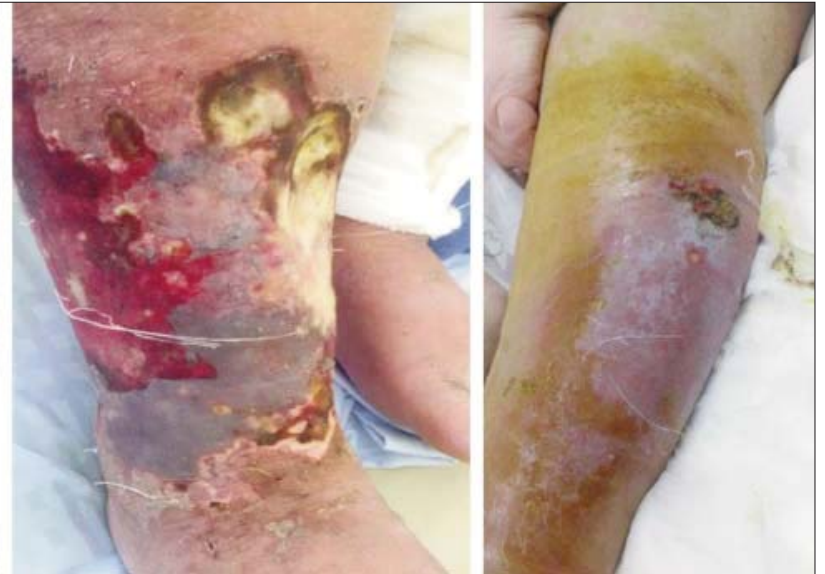

Figure 9. Calf necrotizing fasciitis Figure 10. Calf fasciitis 
sive from the evolutionary point of view were necrotizing fasciitis localized to the limbs, the perineum and the thoracoabdominal wall. This pathological entity has experienced the greatest difficulties in surgical treatment, requiring multiple reinterventions, sustained antibiotic treatment and systemic equilibration, sometimes with unfavorable progression and death through sepsis or multiple organ failure.

The necrotizing fasciitis of the perineum and genitals, known as Fournier gangrene, is commonly found in the diabetic patient and in many cases obese, with profoundly altered immunity. Clinical presentation forms are spectacular, with extensive soft tissue necrosis involving the skin of the perineum, scrotum, penis, hemorrhagic blistering, crepitation and skin fistula with purulent discharge (Figs. 12, 13).

The general condition is profoundly altered, the patient showing signs of prolonged sepsis, fever and chills, tachycardia and sometimes hypotension, asthenia, sometimes lethargy, high glycemic values (in some cases over $500 \mathrm{mg} / \mathrm{dl}$ ), hyperleucocytosis and secondary anemia.

There have been situations in which the clinical presentation of patients with necrotizing fasciitis was extremely discreet from the point of view of the local clinical examination, but increased attention in the examination, integrated in the general context, may reveal alarm signs that will lead to diagnosis (Fig. 14).

In other cases, patient's presentation at the surgeon is delayed, the patient being hospitalized in other specialties (dermatology, diabetes, internal medicine) due to discrete local signs. General signs are unsystematic, generating diagnostic confusions with precious time lost until the local lesions become evident, suggesting the extent (Fig. 15).

Biological test includ complete blood count,

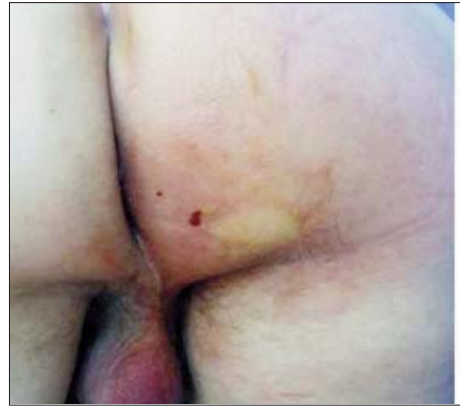

Figure 11. Ischiorectal fossa phlegmon (the puncture extracts purulent liquid which sets the indication of surgica treatment)

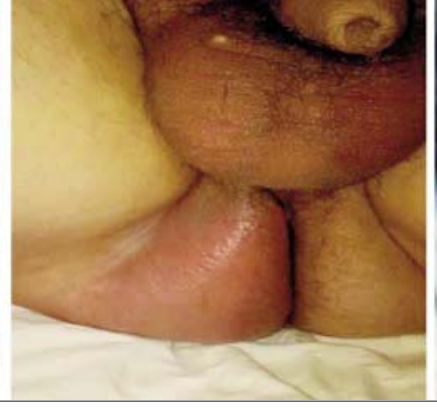

Figure 12.

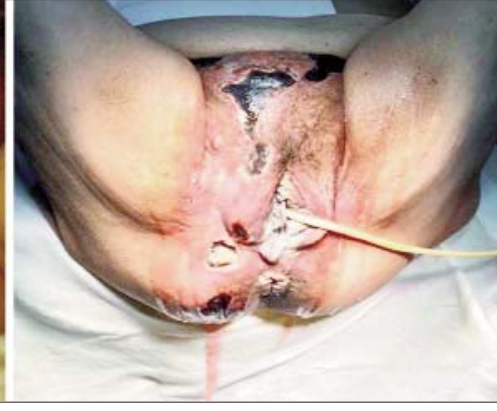

Necrotizing fasciitis of the perineum and labia with multiple fistulas

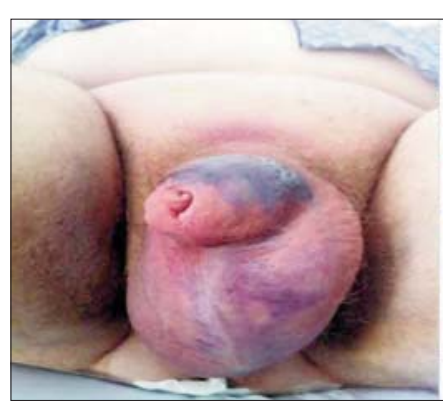

Figure 13. Necrotizing fasciitis of the penis and scrotum

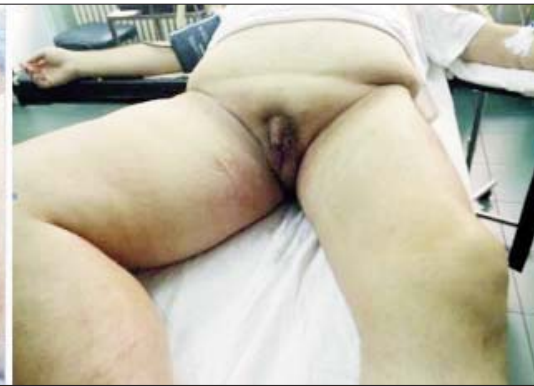

Figure 14. Apparently without obvious changes, but a swelling of the right thigh and the crepitations at the level of the root raises suspicion of an infection with anaerobic germs

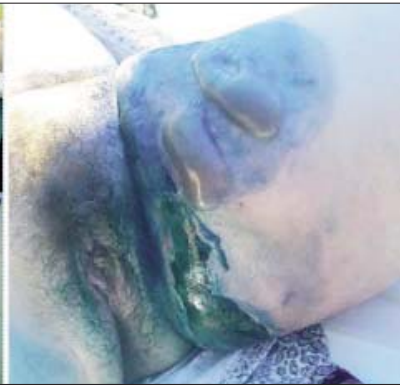

Figure 15. Lesion of necrotizing fasciitis at the root of the left thigh, with areas of skin necrosis, hemorrhagic blisters and crepitation. Inguinal extensive, left labia and posterior thigh 
hepatic and renal tests, coagulation profile, glycemia, ionogram $(\mathrm{Na}, \mathrm{K})$. In patients with major metabolic imbalance an ASTRUP test should be performed. Leukocytosis values had a wide range of variation: patients with advanced local infections had discreet leukocyte growth, but also hyperleukocytosis (values greater than 25,000) (Graphic 16).

The need for vigorous measures of metabolic and acidobasic rebalancing, rehabilitation of circulating volume by proper hydration or blood transfusion (anemia is secondary to prolonged sepsis, but also due to associated pathologies such as chronic renal failure), are required under the condition of the operative emergency character.

In terms of treatment, an extremely important element is the antibiotic therapy. It should be instituted immediately, with an initial empirical character, with broad-spectrum antibiotics subsequently adapted to the antibiogram. The initial antibiotic should act on aerobic gram-positive and gram-negative germs, but also on anaerobic germs. It is known that in the case of extensive, profound lesions such as fasciitis, the flora is in the vast majority polymorphic, and the presence of anaerobes, although difficult to highlight by microbial culture, is always suspected. In our study, an initial combination of cephalosporin of the 3rd generation, quinolone and metronidazole was initially administered. After germ identification, antibiotic therapy was administered according to the antibiogram (patients often received carbapenems or vancomycin) (Graphic 17).

The bacteriological examination from $\mathrm{cul}^{-}$

\section{$n=150$}

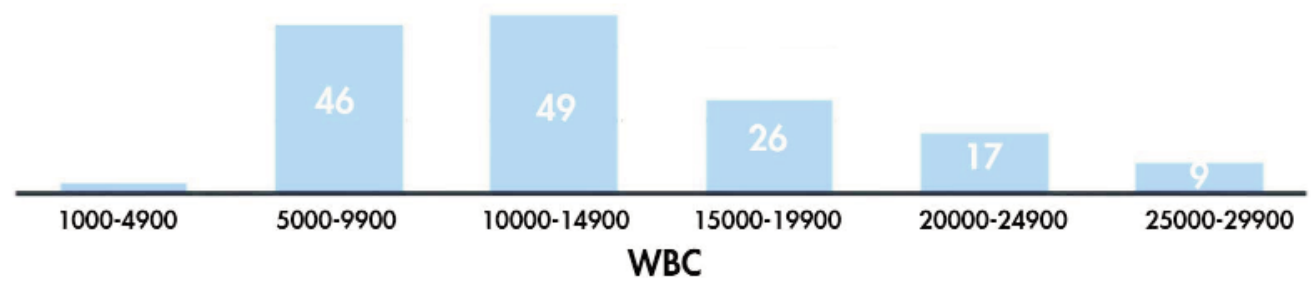

Figure 16. Distribution of patients based on the value of leucocytes at admission

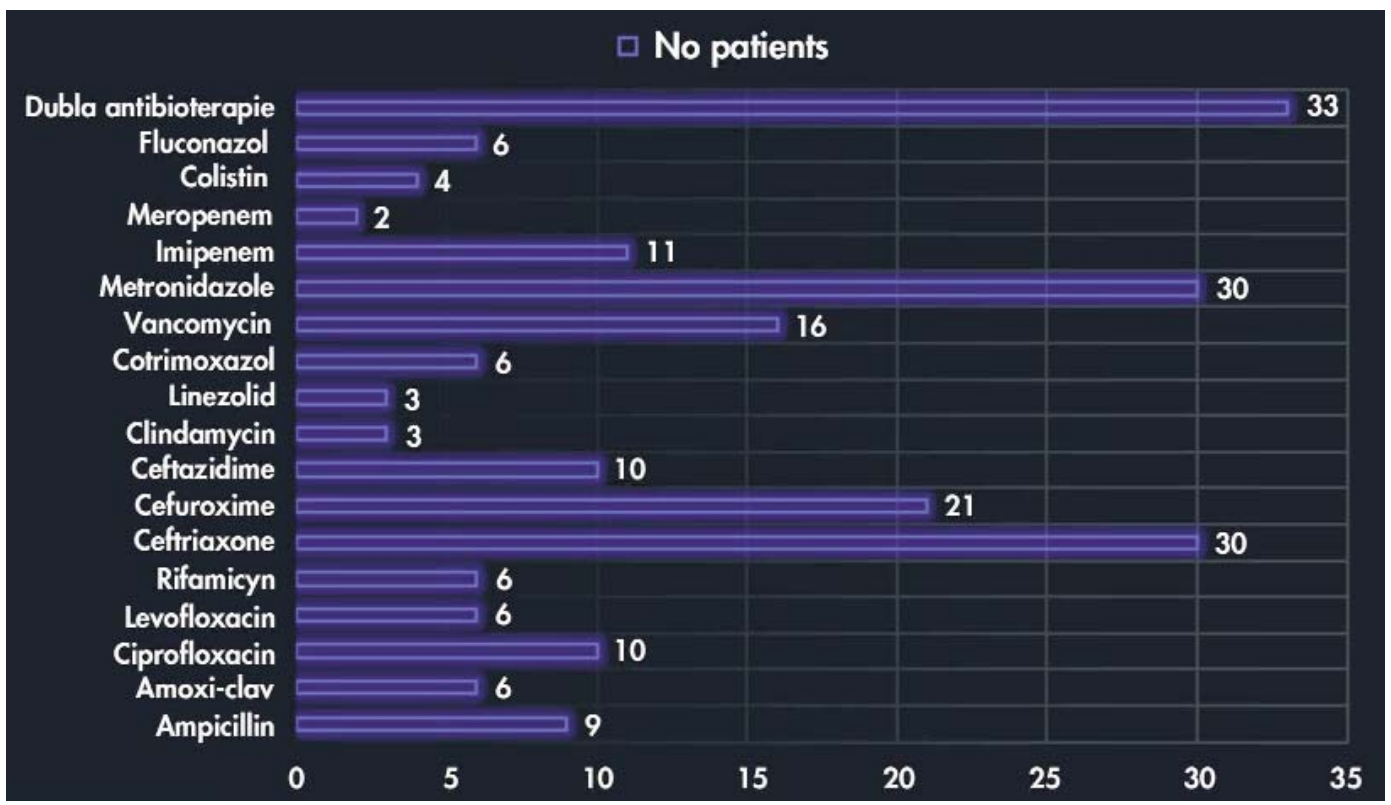

Figure 17. Distribution of the antibiotic therapy 
tures revealed in 39 cases $(26 \%)$ the presence of a polymorphic flora, which gives an increased aggressiveness concretized by the rapid evolution of the lesions. Staphylococcus aureus has been identified in 29 cases (19\%), all of which are necrotizing fasciitis. Although clinically, we can suspect the presence of anaerobic germs, they could not be emphasized in culture media. In 6 cases (4\%) were identified fungi (candida albicans) that required antibiotic association with an antimycotic (Fig. 18).

Surgery is the central element of soft-tissue infections therapy. The 150 patients required 292 surgical interventions. Most of them consisted of excisional debriding and necrectomy
(202), but also treatment that involved major amputations for the removal of the septic outbreak (thigh or calf amputation) when tissue destruction and patient comorbidity required this decision. In 74 cases, post-operative wounds with favorable evolution, showed significant defects in soft parts, especially skin, and it was necessary to perform techniques for covering or reducing the remaining cavity (split skin graft - PPLD, negative pressure therapy and secondary suture) (Fig. 19).

In many cases, serial interventions have been required to identify overdue or newly established suppurative lessions, to continue debridement of new necrotic tissue and wound

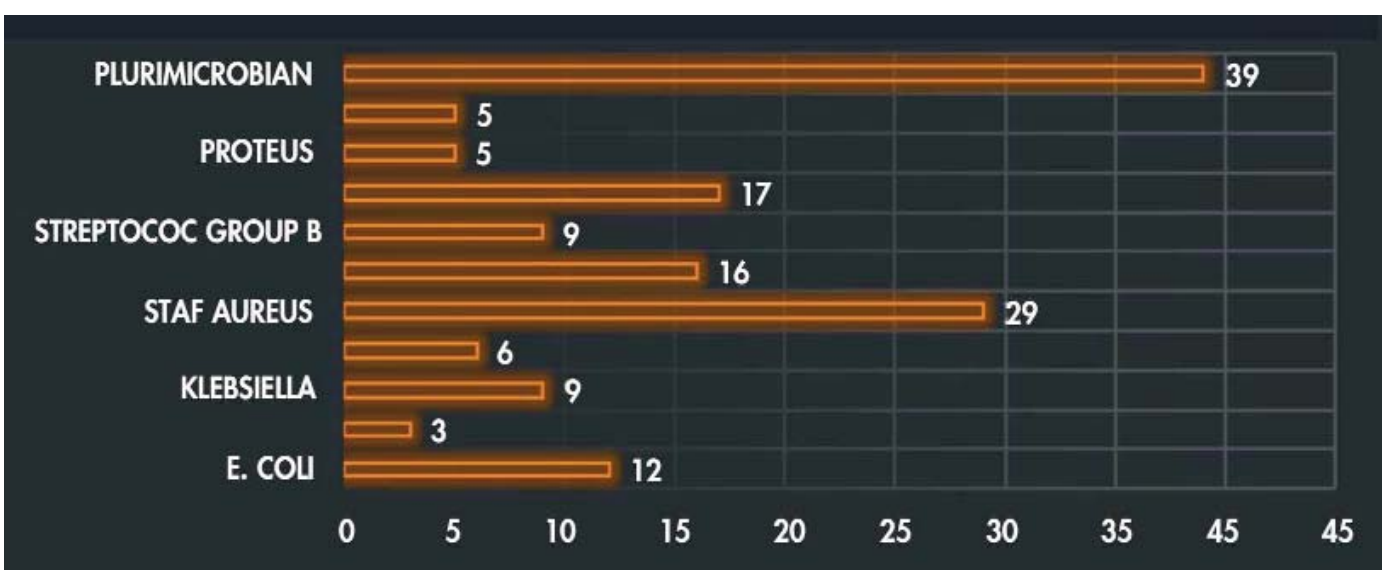

Figure 18. The distribution of the bacteriologic examination results

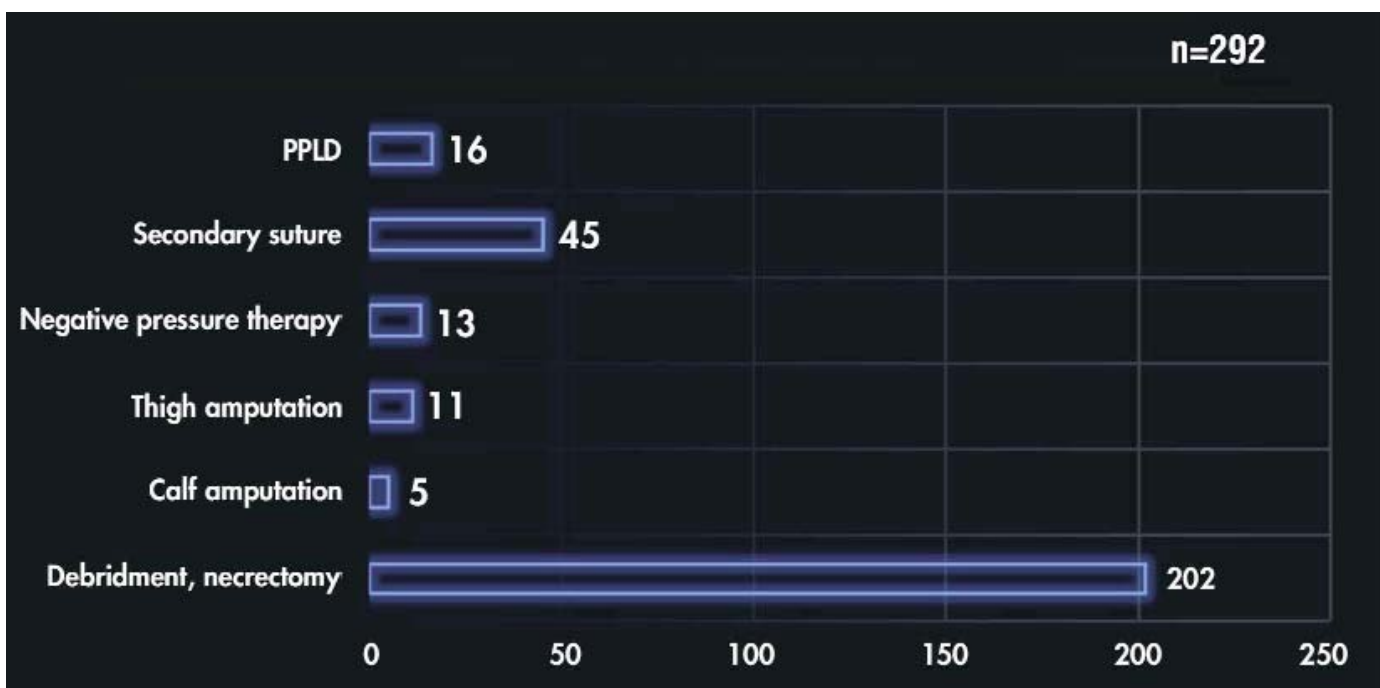

Figure 19. Distribution of the types of surgical interventions 


\section{Number of surgical interventions per pacient}

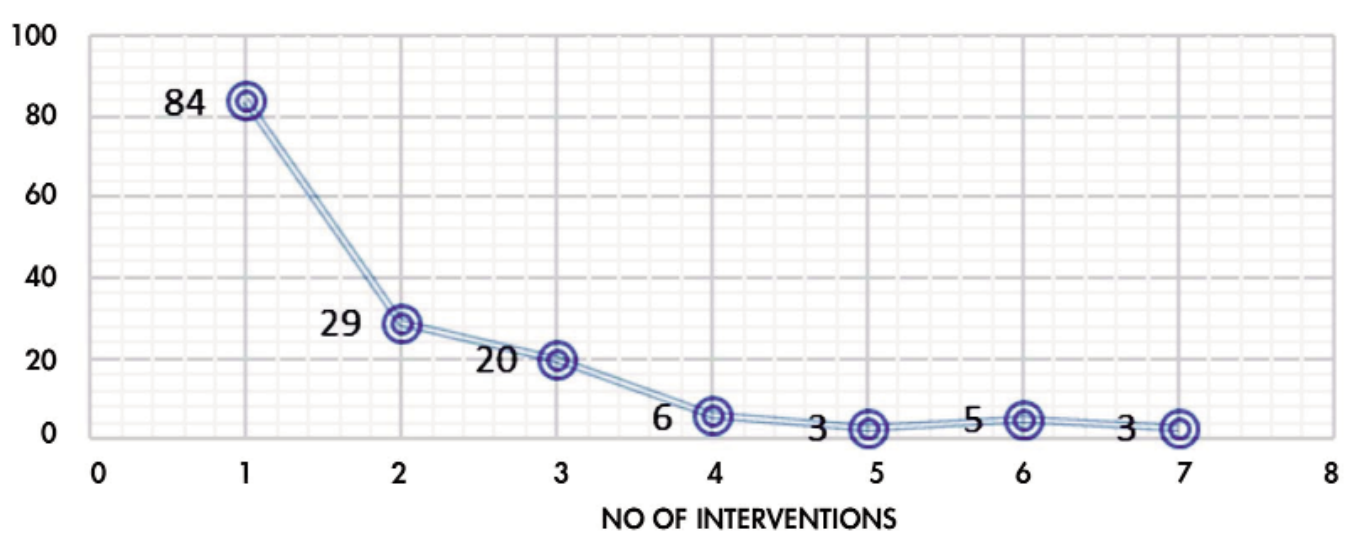

Figure 20. Most patients (56\%) required only one intervention, but in 3 cases the wound evolution required 7 surgical interventions

lavage. In most cases surgical intervention consisted of excisional debridement, necrectomy, fasciectomy, with an open wound and scarring per secundam (Fig. 20).

The surgical intervention consisted of drainage incisions for abscesses, abundant wound lavage with iodine antiseptic solutions and hemostasis control. The surgical wound is carefully explored for the identification of suppurative lessions or communication with other anatomical regions. Finally, the wound remains open, possibly queued to control hemostasis (Figs. 21, 22).

In the case of necrotizing fasciitis surgical intervention is urgently needed. The shortest time from presentation to surgery ensures better postoperative results.

Is illustrative in this regard, the case of a patient with type I diabetes mellitus admitted for thigh necrotizing fasciitis that required 7 surgical interventions. Initially the lesion was located at the level of the medial aspect of the right thigh in the Scarpa triangle. Surgery was performed approximately 4 hours from the time of admission and consisted of a broad skin incision on the inner face of the thigh with debridement and necrectomy of tissues (subcutaneous tissue, fascia, muscle) (Figs. 23, 24).

The need for other surgical interventions was due to the recurrence of necrosis in the postop-

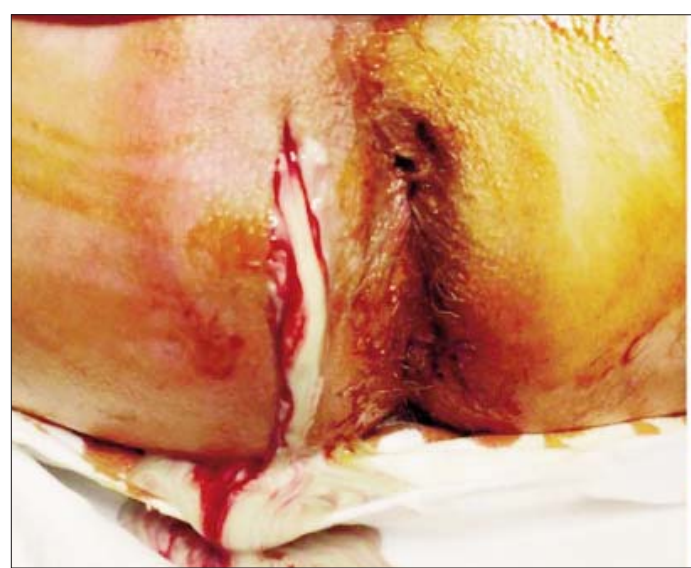

Figure 21. Incision of ischiorectal fossa abscces

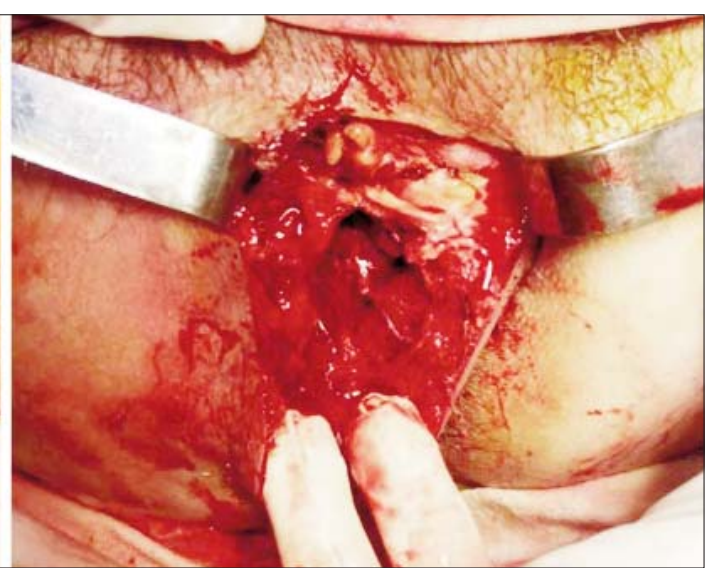

Figure 22. The exploration of the wound to identify suppurative fusions urative 


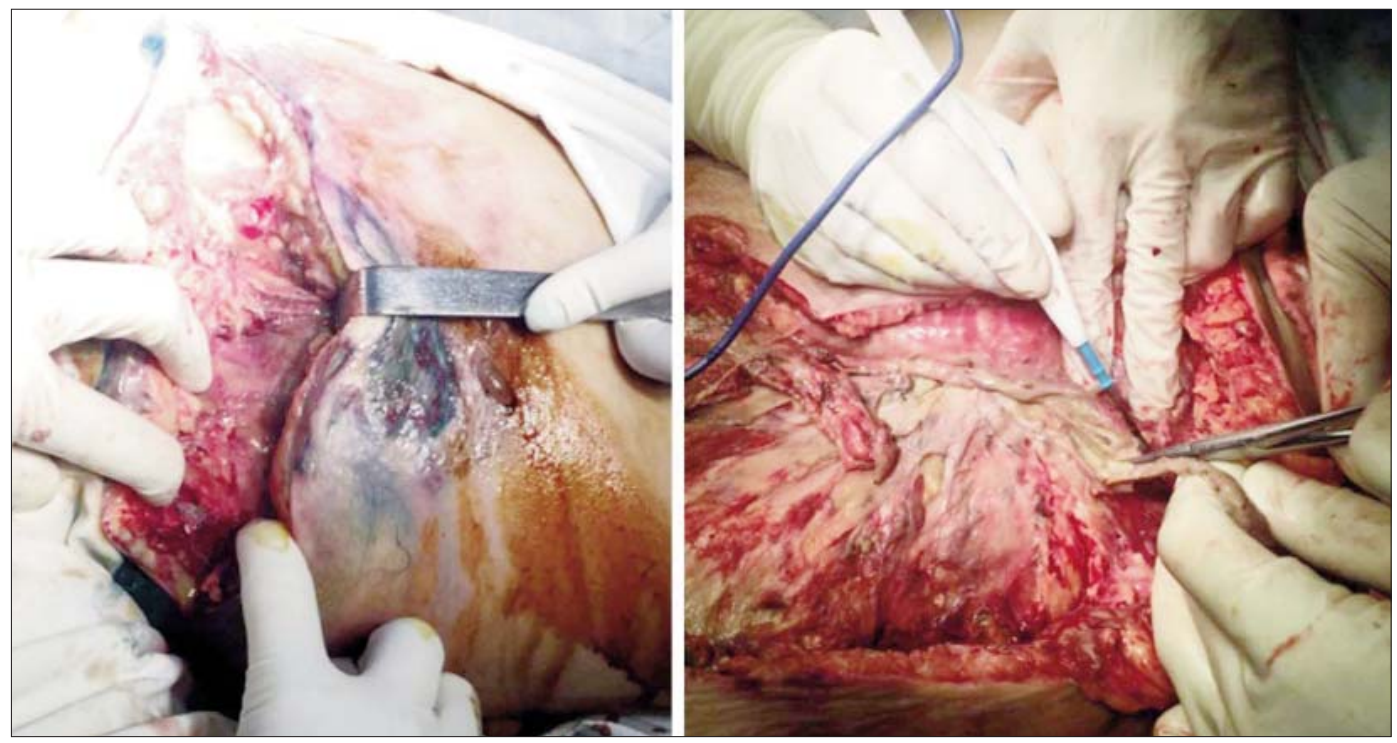

Figure 23. Necrotizing fasciitis antero-medial aspect of the right thigh that required wide excisions
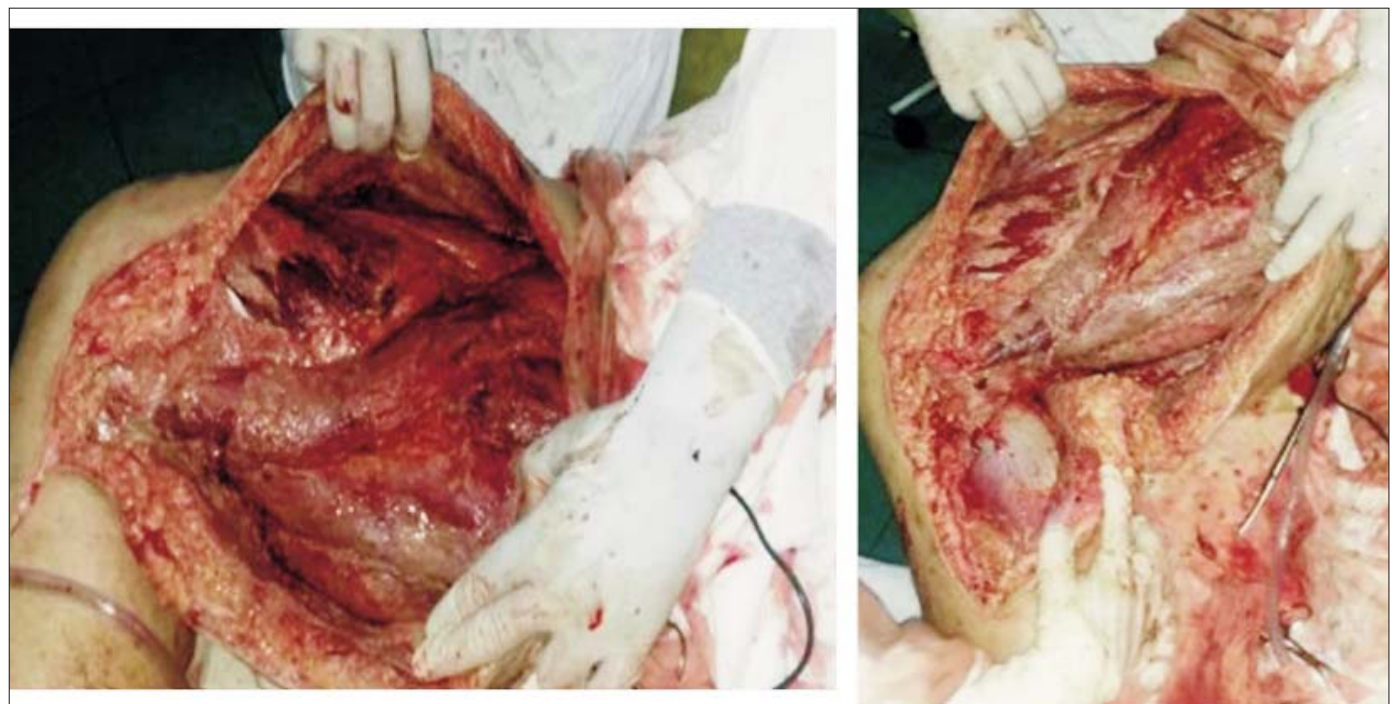

Figure 24. The debridement forced excision of the deep thigh fascia, including muscle excision

erative wound, as well as to the identification of new suppository expansion joints, both inferior to the calf and upper to the anterior abdominal wall. Large incisions and debridment have led to skin necrosis, with near-to-near excision, resulting in an important skin defect.

After obtaining a granulated wound, the skin defect was covered by tegument suture, negative pressure therapy and scarring per secundam (Figs. 25, 26).

For patients with Fournier gangrene, surgery is of immediate urgency. These interventions consist of large excisions, debridations, necrectomies and fasciectomies. The only principle that should lead the surgery is broad excision, wound exploration to identify necrosis extension and their drainage, without taking into account the lack of skin that will result in the postoperative wound. In our cases it required the scrotum, penile and perineal skin excision totally. In one case, orchiectomy was required (it is known that rich testicular vascu- 


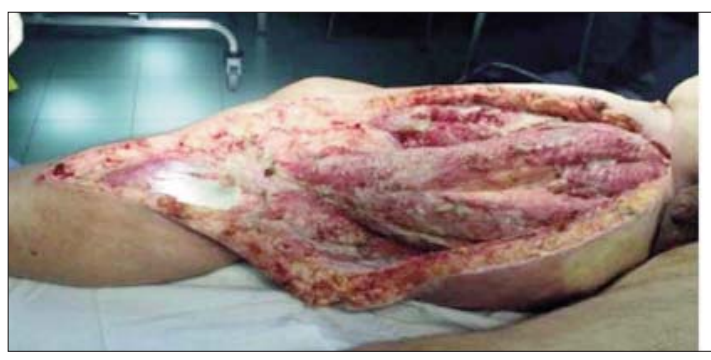

Figure 25. The appearance of the wound with granulation tissue

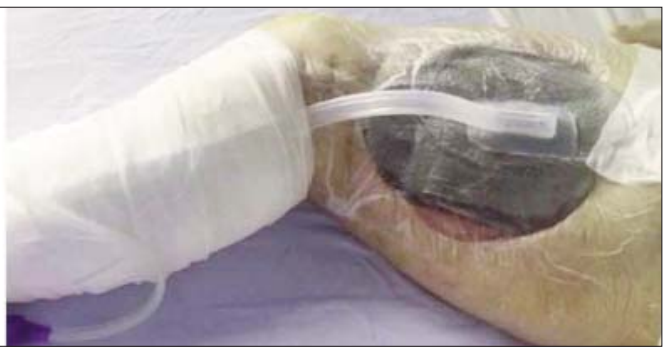

Figure 26. Negative pressure therapy
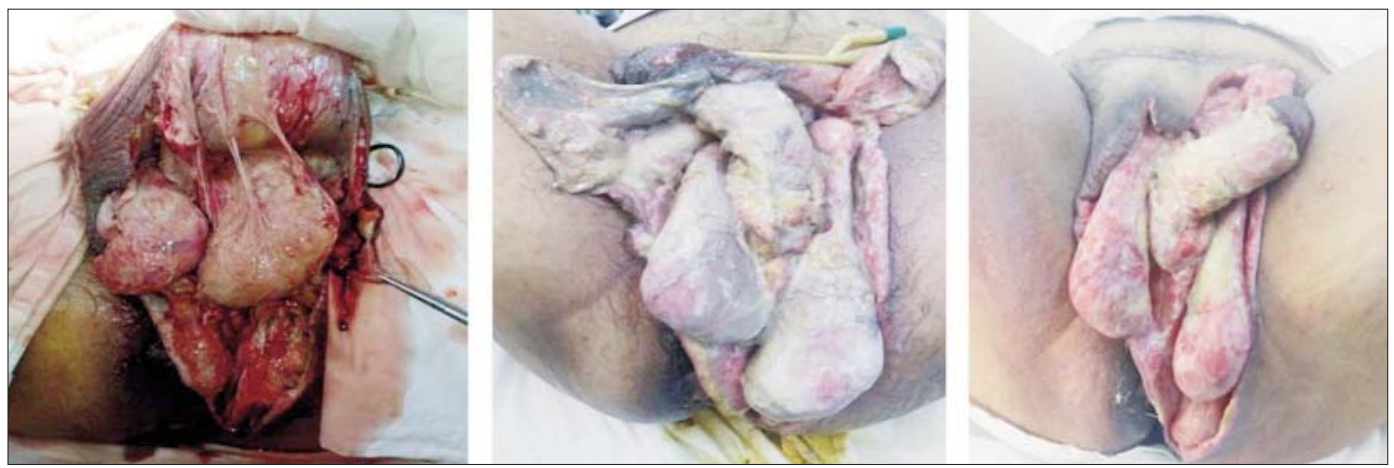

Figure 27. Fournier gangrene - important sacrifice of soft parts (excision of scrotal, penile and perineal skin) with evolution towards granulation

lature provides protection against infection, the testicle being very rarely involved in the infectious process) (Fig. 27).

For skin defects resulting from perineal debridement, partial wound suture of the wound was achieved, with reduction of the remaining space and guiding the scarring. For postoperative skin defects in the scrotum and penis it was necessary the interdisciplinary consult with plastic surgeons and to transfer the patients in specialized units.

Regarding the number of deceased patients, there were 9 cases $(6 \%)$, patients with multiple comorbidities and advanced disease progression, with signs of severe sepsis since admission. Their initial lesion was in 3 cases of necrotizing fasciitis (gas gangrene), and in 6 cases the initial lesion was ischiorectal fossa phlegmon and pelvic limb infections. Deaths occurred through multiple organ failure in 5 patients, respiratory function being among the most commonly affected and difficult to treat requiring antibiotic association and sometimes intubation with mechanical ventilation. In 4 patients death resulted from an acute coronary event (myocardial infarction) justified by a severe associated cardiovascular pathology (diabetic patient developing micro and macroangiopathy more or less advanced which leads to a major risk of producing acute vascular events).

\section{Discusions}

Soft tissue infections in a diabetic patient have numerous features that need to be known and recognized to achieve favorable outcomes.

This pathology can be expressed in many clinical forms, sometimes discreetly local, but with generally important impact (that is why there are many patients going through different specialties until they reach the surgeon - when the lesion is at an advanced stage).

There are peculiarities of metabolic rebalancing (patients with metabolic or renal acidosis, high refractive serum glycaemia requiring high insulin doses) and hydroelectrolytic. Patients mostly have anemic syndrome in the context of severe prolonged sepsis requiring blood transfu- 
sions. Associated pathologies to diabetes, the most important being the vascular lesions at all anatomical levels, generate a major risk of producing acute vascular events (myocardial infarction, vascular accidents, pulmonary or peripheral emboli, etc.). This fact was found when minor surgical interventions for debridement or evacuation of an abscess complicated in the immediate postoperative period with death by myocardial infarction. We found out, regarding the microbial flora, about their increased virulence and their multi-resistance. The association of flora (aerobics, anaerobes and fungi) along with its polymorphism generates extremely aggressive lesions, evolving over several hours by potentiating tissue toxic effects. Regarding the particularities related to antibiotic treatment, we pointed out that it should be initiated immediately with broadspectrum antibiotics that include gram positive, negative and anaerobic germs. Subsequently, the antibiotic should be administered according to the antibiogram, observing, in many situations, multiresistance to the usual antibiotics. Surgical treatment is the central element of soft tissue infections therapy. Emergency surgery, exploration of wounds programmed in the operating room, large debridement, with necrectomy and fasciectomy, are mandatory elements that make the difference to a favorable evolution.

From the multitude of clinical forms that the patient may present at admission, with softtissue infections we will discuss the necrotizing fasciitis, which represents the pathological entity requiring the most diagnostic and treatment efforts, with many clinical variations and unpredictable evolution that associate morbidity and mortality still at elevated levels.

Necrotizing fasciitis is a rare form of infection that initially affects fascias and which subsequently spreads to adjacent tissues, muscle, tegument, subcutaneous tissue $(1,2)$. Without treatment the progression is to sepsis and death, therefore a rapid and aggressive surgical attitude complemented by sustained antibiotic treatment is imperative.

In this context, an early diagnosis is necessary, but it is not always easy to achieve, especially in the forms of primitive necrotic fasciitis, where the gate of the infection can not be identified $(5,6)$. In secondary fasciitis, a properly performed anamnesis with a thorough clinical examination can, in most cases, lead to the identification of a lesion (minor in most cases) that can be considered as the initial septic outbreak. Thus, the existence of small abrasions, lacerations, burns, dermatitis secondary to poor skin hygiene (inguinal, buttock), folliculitis may be sufficient to trigger the pathological process. Otherwise, the initial lesion can be more easily identified in cases of secondary infection of the visceral perforation, perirectal abscesses, infected invasive rectal tumors, cardiac catheterization, laparoscopy or venous sclerotherapy $(6,7,8)$. Signs and symptoms that the patient presents at the time of examination vary with the onset of the disease. Different international institutions (Center for Disease Control and Prevention, National Necrotizing Fasciitis Foundation) have made a group of these symptoms so that the diagnosis of necrotizing fasciitis would be easier to suggest. Minor symptoms occur in the first 24 hours and consist of local signs - moderate progressive pain in the area of recent skin lesions and general signs - diarrhea, fever, nausea, physical asthenia or signs of dehydration. Progressively, in the next 3-4 days, erythema and edema of the anatomical member or region involved and gangrenespecific skin changes are added. Advanced symptoms occur 4-5 days after the onset and are represented by septic shock phenomena (hypotension, neurological changes, oligoanuria, etc.). Typically, the most common signs are tissue necrosis, purulent secretions, intense pain, secondary crepitation because of anaerobic germ infections, and rapid gas progression along the fascial plane.

Who are the patients likely to develop such pathology? Several risk factors have been identified among which diabetes is the most common (9). Sensitive peripheral polyneuropathy secondary to diabetes can explain by hipo / local anesthesia the large number of minor lesions with such developments. Diabetic microangiopathy also leads to tissue hypoxia and predisposes to lesions (10). The state of immuno- 
suppression of the body plays a leading role in the development and progression of the disease $(11,12)$. Along with diabetes mellitus, immunosuppression is also present in patients with chronic alcohol consumption, malnutrition, cancer patients, after chemotherapy or highdose corticoids treatment, polytrauma, chronic renal failure or postpartum $(13,14)$.

The clinical presentation of the patient with necrotizing fasciitis may vary from insidious, progressive evolution to acute, fulminant manifestation (3). Not rarely, there are cases where rapid local development, with soft-tissue necrosis occurs from one hour to the next, require debridement surgery over a few hours.

In the early stages of the disease evolution, local lesions are nonspecific, so they can be confused with other pathologies: cellulitis, impetigo, erysipelas, toxic septic shock. For Fournier gangrene, for example, there may be confusion with orchiepididymitis pain or testicular torsion, which may delay the patient's presentation to the surgeon.

Imaging investigations in necrotizing fasciitis are represented by ultrasonography, computed tomography and the most reliable magnetic resonance imaging. Signs that support such diagnostic are extensive involvement of the deep intermuscular fasciae, thickening to more than $3 \mathrm{~mm}$ and partial or complete absence on post-gadolinium images of signal enhancement of the thickened fasciae.

Computer tomography imaging and nuclear magnetic resonance imaging investigations, although they are highly specific imaging methods, are often unavailable in many sanitary units and time consuming. Some authors propose a rapid imaging diagnostic method, ultrasonography with assessment of subcutaneous tissue status, presence of gas and fascial necrosis (STAFF technique) (15). As far as we are concerned, careful clinical examination, with the identification of the first signs of deep infection, supplemented by transcutaneous aspiration puncture in the fluctuating area which evidences purulent fluid, suggests the presence of the infection and establishes the surgical indication in emergency.

In conclusion, in acute form of presentation, the diagnosis of necrotizing fasciitis is eminently clinical. Imaging can confirm deep tissue involvement and evaluate lesion spread but never delay surgical treatment.

From the pathophysiological point of view, bacterial development leads to the release of endo and exotoxins, affecting microcirculation leading to ischemia and necrosis (16). Thrombosis of the venous and arterial circulation at the skin and subcutaneous tissue generates gangrene. In the early stages of disease evolution, apparently the skin can have a normal appearance even under the conditions of an extensive deep infection, many dermal capillaries may be thrombosed before suggestive changes in necrosis occur (17).

The bacterial population involved in the pathological process and the rapid destructive character of necrotizing fasciitis suggest a symbiotic and polymicrobial synergy (18). Hemolytic A beta-group streptococci has been identified in most infections, sometimes as the only pathogen, especially in diabetic patients with associated severe vascular pathology, generating necrotizing fasciitis more frequently in the lower limbs $(19,20)$. However, polymicrobial infection is the rule, the association between anaerobic and aerobic germs being very common. Thus, we can identify bacteroides, clostridium, peptostreptococcus, enterobacteriaceae, coliforms (E. coli), proteus, pseudomonas, klebsiella.

Depending on the microbial flora, necrotizing fasciitis were divided into four types (21). Type I is a polymicrobial form, representing $70-90 \%$ of cases. In particular, it affects the perineum and the trunk and is associated with comorbidities such as diabetes. Type II is monomicrobian, most commonly being hemolytic A beta streptococcus. Other germs identified may be S. pyogenes, S. Aureus (22). This type of infection occurs after incisions and seems to be correlated with the administration of non-steroidal antiinflammatory drugs (23). It develops especially in the limbs, with evolution towards toxic-septic shock and death. Type III includes monomicrobial infection of the clostridium species or gram negative bacteria. It occurs in polytraumatized patients or secondary to postoperative wounds 
(24). Type IV is the result of infection with fungi, mainly candida and zygomycetes. It occurs in severely immunocompromised patients or in severe polytrauma patients.

Laboratory tests are not specific, but should look for elements that suggest the presence of severe sepsis. Usually, leukocytosis is greater than 20,000 elements $/ \mathrm{mm}^{3}$, renal constants are altered confirming renal insufficiency of varying degrees (25). In order to establish an early diagnosis, based on laboratory analyzes, several score systems were developed, the most important being The Laboratory Risk Indicator for Necrotizing Fasciitis (LRINEC) and the Fournier's Gangrene Severity Index (FGSI) who divided patients into risk categories (26).

Treatment should be initiated as soon as the positive diagnosis has been confirmed (27). The patient should be admitted to an emergency surgery unit with a team trained and competent to manage such pathology. Hemodynamic parameters should be monitored with intensive support of vital functions. Diabetic patients require metabolic and hydroelectrolytic rebalancing, insulin therapy giving a better control of glycemic values. We find that high glycemic values, which do not normalize under properly managed treatment, suggest the existence of an "irritating spine", well-defined collections or diffuse infections, and postoperatively the presence of overlapping septic outbursts, extensive fusions requiring surgical reinterventions. Monitoring of diuresis is an important element in the follow-up of the patient, the presence of oligoanuria being of significance unidentified septic outbreaks.

Treatment is based on two key elements: surgery and antibiotic treatment.

Antibiotic treatment should be initiated immediately, initially empirically with broad spectrum antibiotics that act on gram positive, gram negative and anaerobic flora. Although tissue ischemia and hypoxia, by compromising microvascularization, lead to poor exposure of the antibiotic in the infected anatomical region, antibiotic treatment remains an essential element of therapy (28). Initially, penicillins and cephalosporins antibiotics associated with metronidazole and clindamycin will be administered (29). The antibiogram from bacterial cultures should be followed closely, including the anaerobic and fungi culture. Carbapenem treatment is recommended for patients with aggressive germs selected in hospital settings. For methicillin-resistant aureus staphylococci (MRSA), treatment with vancomycin or linezolid is required $(30,31)$. In the case of positive cultures for fungi, treatment with fluconazole or amphotericin B, medications with high toxicity and relative efficacy, will be given. Antibiotic treatment should be continued for 5 days after local signs and symptoms have disappeared, with the average time of antibiotic therapy being 4-6 weeks (32). There are authors who support the beneficial effect of immunoglobulins administered intravenously by neutralizing toxins generated by streptococcal infections, by the positive effect that high doses of immunoglobulin generate in streptococcal infections (33, 34).

Surgery is the central element of treatment in necrotizing fasciitis. Rapidly initiated surgery and broad debridement are favorable prognostic factors (35-37). In addition, excisions from the first signs of infection lead to a lesser substance lost in postoperative wounds, in some cases eliminating the need for major amputations $(38,39)$. Surgical treatment should undergo extensive and profound debridement, beyond necrosis to healthy tissue.

The question is how much should it be excised from the skin tissues. It is known that at the skin level there are vascular and vasculitis microthrombosis generated by bacterial exotoxins located in the entire thickness of the skin, so that the seemingly normal initial skin will subsequent be affected by ischemia and necrosis (40). All necrotic tissue has to be excised, and this is accomplished by careful exploration of the wound in the operating room (eliminating necrotic-suppressive expansion fusions and excision of all tissues that detach easily from the deep fascial plane). Irigation of the wound, including hydrogen peroxide, with double effect, effervescent removal of cellular debris and bactericidal 
effect on anaerobic germs must be carried out. Large debridments will result in multiple vascular bursts, so the need for effective hemostasis is required. The plague will be watched postoperatively, both at the patient's bed and in the operating room, and in most cases the scheduled excisional debridments are the rule. The wound will remain open until all necrotic tissue is removed and replaced with granulation tissue. Dressings will be performed at the patient's bed and in the surgery room, using antiseptics or dressings impregnated with silver salts or antibiotics with a bactericidal effect. Also, using ointments that perform an enzymatic debridement is in many cases necessary. In the case of granular wounds, there is always a significant skin defect. In these cases, the partial secondary suture for dimensional reduction of the remaining wound can be achieved by dissecting the adjacent skin flaps.

Negative pressure therapy is used in many surgical specialties for the purpose of wound closure due to rapid results and increased efficacy (41). Negative pressure therapy consists of a sterile closed-circuit system consisting of a sponge covering the wound, above which the system is sealed with a self-adhesive foil fixed over the sponge. Connected to a suction device with a reservoir that will generate a variable negative pressure. The effect is aspiration of wound exudation and bacteria as well as improvement of microcirculation, both effects leading to rapid healing compared to classical dressings (42). The wound will be re-evaluated every 48-72 hours, and as needed, the aspiration can be resumed for another cycle.

Plastic surgery can offer, in selected cases, the best alternatives to cover the skin defect by splitting skin graft, flaps or myocutaneous flaps (43).

\section{Conclusions}

Soft tissue infections in the diabetic patient have a heterogeneous appearance with specific features requiring careful clinical examination, multidisciplinary treatment, serious and aggressive surgery to control the growing aggression of the germs involved. Careful follow-up of the wounds and the general condition of the patient, several times a day, rapid therapeutic decisions adapted to each case are essential for achieving good postoperative results. In the case of necrotizing fasciitis, a high mortality rate remains, up to $32 \%$ after surgical treatment and almost 100\% without treatment.

\section{Funding Details}

This research did not receive any specific grant from funding agencies in the public, commercial or not-for-profit sectors.

\section{Conflict of Interest}

All author declare that they have no conflict of interest.

\section{Human Rights}

All procedure followed have been performed in accordance with the ethical standards laid down in the 1964 Declaration of Helsinki and its later amendments.

\section{Informed Consent}

Informed consent was obtained from all patients for being included in the study.

\section{Author's Contributions}

All authors have equal contributions.

\section{References}

1. Misiakos EP, Bagias G, Patapis P, Sotiropoulos D, Kanavidis P, Machairas A. Current Concepts in the Management of Necrotizing Fasciitis. Frontiers in Surgery. 2014;1:36.

2. Hakkarainen TW, Kopari NM, Pham TN, Evans HL. Necrotizing soft tissue infections: Review and current concepts in treatment, systems of care, and outcomes. Current problems in surgery. 2014;51(8):344-362.

3. Carter PS, Banwell PE. Necrotising fasciitis: a new management algorithm based on clinical classification. Int Wound J. 2004; 1:189-98.

4. Taviloglu K, Gunay K, Ertekin C, Gencosmanoglu R, Turel Necrotizing fasciitis: therapeutical modalities (in Turkish) Turk J Surg. 1996;12:128-33.

5. McHenry CR, Brandt CP, Piotrowski JJ, Jacobs DG, Malangoni MA. Idiopathic necrotizing fasciitis: recognition, incidence, and out- 
come of therapy. Am Surg. 1994;60:490-4.

6. Yanar H, Taviloglu K, Ertekin C, Guloglu R, Zorba U, Cabioglu N, et al. Fournier's gangrene: risk factors and strategies for management. World J Surg. 2006;30:1750-4.

7. Chan HT, Low J, Wilson L, Harris OC, Cheng AC, Athan E. Case cluster of necrotizing fasciitis and cellulitis associated with vein sclerotherapy. Emerg Infect Dis. 2008;14(1):180-1.

8. Bharathan R, Hanson M. Diagnostic laparoscopy complicated by group A streptococcal necrotizing fasciitis. J Minim Invasive Gynecol. 2010;17(1):121-3

9. Francis KR, Lamaute HR, Davis JM, Pizzi WF. Implications of risk factors in necrotizing fasciitis. Am Surg. 1993;59(5):304-8.

10. McArdle P, Gallen I. Necrotizing fasciitis in diabetics. Lancet. 1996; 348(9026):552.

11. Nothwang J, Ulrich C. Necrotising fasciitis-cryptogenic infection following posttraumatic immunopathy. Arch Orthop Trauma Surg. 1998;118(3):167-71.

12. Sudarsky LA, Laschinger JC, Coppa GF, Spencer FC. Improved results from a standardized approach in treating patients with necrotizing fasciitis. Ann Surg. 1987;206(5):661-5.

13. McHenry CR, Piotrowski JJ, Petrinic D, Malangoni MA. Determinants of mortality for necrotizing soft-tissue infections. Ann Surg. 1995;221(5):558-63; discussion 563-5.

14. Elliott DC, Kufera JA, Myers RA. Necrotizing soft tissue infections: risk factors for mortality and strategies for management. Ann Surg. 1996;224(5):672-83.

15. Castleberg E1, Jenson N1, Dinh VA2. Diagnosis of necrotizing faciitis with bedside ultrasound: the STAFF Exam. West J Emerg Med. 2014;15(1):111-3.

16. Sarani B, Strong M, Pascual J, Schwab CW. Necrotising fasciitis: current concepts and review of the literature. J Am Coll Surg. 2009; 208(2):279-88

17. Wong $\mathrm{CH}$, Wang YS.The diagnosis of necrotising fasciitis. Curr Opin Infect Dis. 2005;18(2):101-6.

18. Quirk WF Jr, Sternbach G. Joseph Jones: infection with flesh eating bacteria. J Emerg Med. 1996;14(6):747-53.

19. Bahebeck J, Sobgui E, Loic F, Nonga BN, Mbanya JC, Sosso M. Limb-threatening and life-threatening diabetic extremities: clinical patterns and outcomes in 56 patients. J Foot Ankle Surg. 2010; 49(1):43-6

20. Stone DR, Gorbach SL. Necrotizing fasciitis. The changing spectrum. Dermatol Clin. 1997;15(2):213-20.

21. Morgan MS. Diagnosis and management of necrotising fasciitis: a multiparametric approach. J Hosp Infect. 2010;75(4):249-57.

22. Weiss KA, Laverdière M. Group A Streptococcus invasive infections: a review. Can J Surg. 1997;40(1):18-25.

23. Souyri C, Olivier P, Grolleau S, Lapeyre-Mestre M. French network of pharmacovigilance centres. Severe necrotizing soft-tissue infections and nonsteroidal anti-inflammatory drugs. Clin Exp Dermatol. 2008;33(3):249-55

24. Yeung YK, Ho ST, Yen CH, Ho PC, Tse WL, Lau YK, et al. Factors affecting mortality in Hong Kong patients with upper limb necrotising fasciitis. Hong Kong Med J. 2011;17(2):96-104.

25. Wong C, Khin L. Clinical relevance of the LRINEC (laboratory risk indicator for necrotizing fasciitis) score for assessment of early necrotizing fasciitis. Crit Care Med. 2005;33(7):1677.

26. Chao WN, Tsai SJ, Tsai CF, Su CH, Chan KS, Lee YT, et al. The Laboratory Risk Indicator for Necrotizing Fasciitis score for discernment of necrotizing fasciitis originated from Vibrio vulnificus infections. J Trauma Acute Care Surg. 2012;73(6):1576-82.
27. Stevens DL, Bisno AL, Chambers HF, Dellinger EP, Goldstein EJ, Gorbach SL, et al. Practice guidelines for the diagnosis and management of skin and soft tissue infections: 2014 update by the infectious diseases society of America. Clin Infect Dis. 2014; 59(2):147-59.

28. Marron CD. Superficial sepsis, cutaneous abscess and necrotizing fasciitis. In: Brooks A, Mahoney PF, Cotton BA, Tai N, editors. Emergency Surgery. Oxford, UK: Blackwell Publishing; 2010. p. 115-23.

29. Lille ST, Sato TT, Engrav LH, Foy H, Jurkovich GJ. Necrotizing soft tissue infections: obstacles in diagnosis. J Am Coll Surg. 1996; 182(1):7-11.

30. Zimbelman J, Palmer A, Todd J. Improved outcome of clindamycin compared with beta-lactam antibiotic treatment for invasive Streptococcus pyogenes infection. Pediatr Infect Dis J. 1999;18(12):1096-100.

31. Mulla ZD. Treatment options in the management of necrotising fasciitis caused by group Streptococcus. Expert Opin Pharmacother. 2004;5(8):1695-700.

32. Naqvi GA, Malik SA, Jan W. Necrotizing fasciitis of the lower extremity: a case report and current concept of diagnoses and management. Scand J Trauma Resusc Emerg Med. 2009;17:28. .

33. Norrby-Teglund A, Muller MP, Mcgeer A, Gan BS, Guru V, Bohnen $\mathrm{J}$, et al. Successful management of severe group A streptococcal soft tissue infection using an aggressive medical regimen including intravenous polyspecific immunoglobulin together with a concervative surgical approach. Scand J Infect Dis. 2005;37(3): 166-72.

34. Kaul R, McGeer A, Norrby-Teglund A, Kotb M, Schwartz B, O'Rourke $\mathrm{K}$, et al. Intravenous immunoglobulin therapy for streptococcal toxic shock syndrome; a comparative observational study. Clin Infect Dis. 1999;28(4):800-7.

35. Chelsom J, Halstensen A, Haga T, Høiby EA. Necrotising fasciitis due to group A streptococci in western Norway: incidence and clinical features. Lancet. 1994;344(8930):1111-5.

36. Edlich RF, Wind TC, Heather CL, Thacker JG. Reliability and performance of innovative surgical double-glove hole puncture indication systems. J Long Term Eff Med Implants. 2003; 13(2):69-83.

37. Wang $\mathrm{KC}$, Shih $\mathrm{CH}$. Necrotizing fasciitis of the extremities. J Trauma. 1992;32(2):179-82.

38. Kaufman JL. Clinical problem-solving: necrotizing fasciitis. N Engl J Med. 1994;331(4):279;

39. Adams EM, Gudmundsson S, Yocum DE, Haselby RC, Craig WA, Sundstrom WR. Streptococcal myositis. Arch Intern Med. 1985; 145(6):1020-3.

40. Andreasen TJ, Green SD, Childers BJ. Massive infectious softtissue injury: diagnosis and management of necrotizing fasciitis and purpura fulminans. Plast Reconstr Surg. 2001;107(4):1025-35.

41. Netscher DT, Baumholtz MA, Bullocks J. Chest reconstruction: II. Regional reconstruction of chest wall wounds that do not affect respiratory function (axilla, posterolateral chest, and posterior trunk). Plast Reconstr Surg. 2009;124(6):427e-35e.

42. Mouës CM, van den Bemd GJ, Heule F, Hovius SE. Comparing conventional gauze therapy to vacuum-assisted closure wound therapy: a prospective randomised trial. J Plast Reconstr Aesthet Surg. 2007;60(6):672-81. Epub 2006 Jun 22.

43. Karian LS, Chung SY, Lee ES. Reconstruction of Defects After Fornier Gangrene: A Systematic Review. Eplasty. 2015;15:e18. eCollection 2015 